\title{
Prisoner doctor in a Soviet labour camp 1940-1
}

\author{
J J Geller
}

I was born in Gorlice in southern Poland and studied medicine at the Jagiellonian University in Cracow, where I obtained my MD in 1934. I started my first medical practice there while working at the nearby Bonifrater Hosptial and in 1936 married Zosia, my cousin and fellow student, who was working as a dentist. Our surgeries were side by side and shared a modest waiting room.

Those were happy times. Living was inexpensive, the work was pleasant, and gradually we both built up our practices, which together produced an income that was satisfactory without being luxurious. Unfortunately, by 1939 the virus of antisemitism was spreading from Germany. Early in that year a motion was proposed to the Polish Medical Association in Cracow that Jewish doctors should be deprived of their membership, and soon afterwards I received a letter stating that my services at the hospital were no longer required.

In the second half of 1939 there was confusion among the citizens of Cracow over what they should do about the dreadful stories of Nazi atrocities that they heard from the hundreds of Jewish refugees streaming into the city from Germany and other European countries. No guidance or advice was forthcoming from the Polish government, which had fled to Switzerland in the face of the overwhelming German invasion force.

As the Germans began their advance on Cracow my wife and I had to consider what we should do. No one then really believed the stories of mass exterminations of Jewish people as it was thought that a civilised country such as Germany would be incapable of such acts. In any case, we naïvely supposed that in the event of an occupation only the Polish men would be harrassed and that the women, even the Jewish ones, would not be harmed. In the circumstances, however, we decided that it would be safer for both of us if I left Cracow and made my way to eastern Poland.

Accordingly, I gathered together a few clothes, my identity card and medical qualifications, my emergency case containing my instruments, a small stock of drugs, and my Polish vade mecum. With these I set out, hoping to cross the San river to take refuge in a province that was then occupied by Soviet forces.

\section{Arrest by the Russians}

My plan, unfortunately, did not succeed, and I was arrested by Russian troops in the railway station at Przemysl, only a few kilometres from the river. The morning of 3 February found me packed into a cell with almost 100 others, with my identity card, medical qualifications, and emergency case all taken from me by an officer of the KGB, who promised that I would be released and my possessions restored to me within 48 hours.

As things turned out I was detained in Przemysl for 12 days and then taken by night and under guard back to the railway station to join hundreds of other prisoners, who were surrounded by Russian guards armed with machine guns. The guards herded us into cattle trucks, 30, 40, and sometimes more to each truck. There was no heating in the train despite the Croydon CR0 5DG

$\mathrm{J} \mathrm{J}$ Geller, MD, retired general practitioner

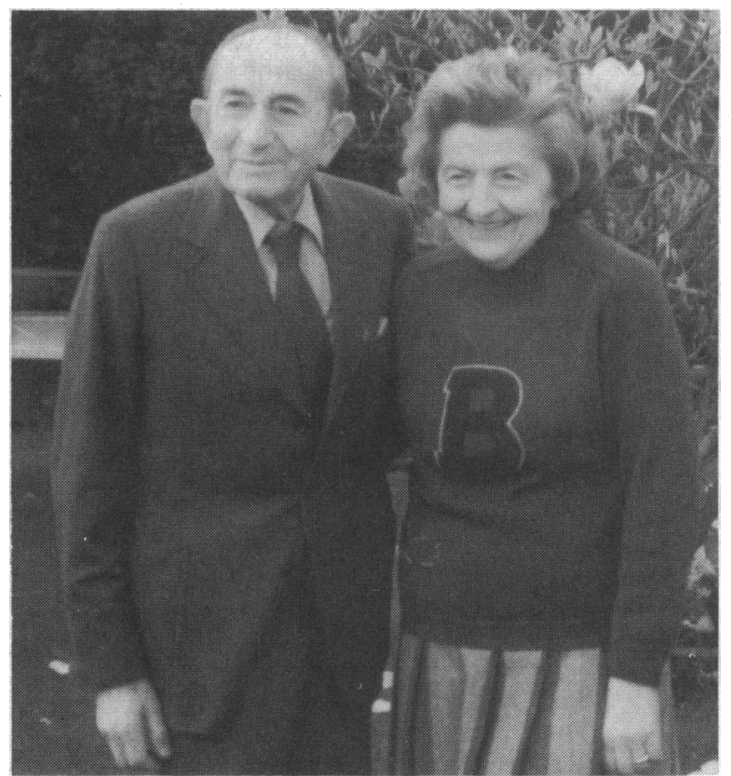

The author and his second wife, Blanca

down, although some of us managed to doze in a squatting position.

The only food was a piece of bread each day and a little water. A large container in each truck served as a toilet and was emptied by the prisoners at the stations en route. No washing facilities were available during the journey, which was both frightening and depressing, crowded as we were into wagons with barred windows and not knowing where we were going or what awaited us when we reached our destination.

After travelling for over $600 \mathrm{~km}$ we arrived at Odessa on about 12 March 1940 and were transferred to the prison there. I was introduced to the other prisoners assembled in the courtyard by the Russian commanding officer, who described me as "the Polish doctor from Cracow who is a drug smuggler." This was because some medicines had been found in my emergency case when I was arrested.

Our group was allocated to block 49 of the building, which contained dozens of cells each about seven by four metres. During the weeks up to the end of September we were called in turn to the KGB establishment office in the prison for questioning. There I was coerced by threats of reprisals against my wife and relatives into signing a false confession implicating me in carrying drugs and in crossing into Soviet territory without permission. For these "offences" I was sentenced to serve for three years in a corrective labour camp. Luckily, this was one of the shortest sentences I could have received, as many of my fellow prisoners were sentenced to five, eight, and even 10 years.

\section{Life as a prisoner doctor}

My sentence began in the Krasnyj Paxar camp near Kuybyshev. At first I was treated as an ordinary prisoner, but after about a week I was summoned to the chief medical officer, Dr Viktor Pavlovich, a Russian who was not a prisoner and who spoke some Polish. He was accompanied by an officer in KGB uniform who probably also understood Polish. I was asked for my 
identity card and evidence that I really was a doctor, and I had to explain that these documents had been taken from me on my arrest and not returned. Dr Pavlovich then apologised and explained that he would have to question me to assure himself of my competence. I passed my examination on cardiac and renal topics, but my knowledge of pellagra was not considered to be up the standard required of a doctor who was going to be employed in a labour camp. He therefore suggested that I made a further study of pellagra and also learnt to speak and write Russian. With the help of some fellow prisoners I quickly became fluent in Russian because of its similarity to Polish, and this new knowledge was soon put to the test when I was called to attend Dr Pavlovich himself when he collapsed one day in the camp. I was surprised that as a prisoner doctor lacking any documentary evidence of qualifications I had been called to treat the chief doctor of the camp, and at his own request.

At the beginning of my stay there were over 2000 prisoners in the camp, and to deal with these there were two catetories of medical employees. The first were "free," living locally or coming from different parts of Russia. Some were civilian employees, others army doctors, nurses, and feldshers (doctors' assistants or rather more experienced male nurses). The second category consisted of prisoner doctors (Polish), Polish dentists, feldshers, and other auxiliary staff. $\mathrm{Mr}$ Chernishev, a free feldsher in his 50s, took charge of me almost paternally, guiding me gently on how to proceed, and above all giving me an idea about the nature of the work in the camp. I was instructed by the medical officer to take morning and evening surgeries and to look after one of the hospital barracks.

\section{My patients}

Morning surgeries started around $5 \mathrm{am}$, before the first shift of prisoners went off to outside building or factory work-always accompanied by guards. The evening surgery started at $530 \mathrm{pm}$ or later and was intended for prisoners on return from their work, and also for men on the second night shift. The surgeries were always crowded, but in my necessarily limited time I listened to my patients and tried to relieve their anxieties with a mixture of sympathetic words and bromides. For some of the prisoners attendance at the surgery was merely an excuse, an attempt to get a certificate of incapacity for work for a few days, but, unfortunately, I was not in a position to please everyone. It was a great relief to be able to give a prisoner a chance to clean his bunk in the barracks, to write a letter to his family, to wash his shirt, and to have a rest.

I tried not to use medical jargon when talking to the patients as this might not have been comprehensible to them. To be prepared to listen and talk to those in distress was of the greatest importance, and I was always prepared to discuss their problems and complaints. I treated my patients along unconventional lines, but at the same time I avoided undue familiarity. Had I not done so I would have lost their respect; a sense of discipline had to be preserved. Mine was a difficult job, and I realised that I was vulnerable in being responsible for every certificate issued for incapacity to work. I knew that I would be checked by Dr Avchennikova, a major in the KGB, and I had to be careful not to overdo it as a list of prisoners certified unfit for work by the doctors and feldshers was presented every morning in her office. I tried to be more liberal with the group of patients aged over 40 and cautious with the younger group unless I found some genuine reason for incapacity. The older prisoners needed more attention and above all more moral support. Admission to the hospital for seven to
14 days, or longer if possible, was effective in ameliorating their despair. Clean bunks, warmer accommodation, washing facilities, better food, and contact with other patients in the wards made a tremendous difference to their health and mental outlook.

The prisoners' main complaints were muscle and joint pains, colds, coughs, weakness, loss of weight, and, particularly, symptoms of nutritional disorders related to vitamin deficiencies, such as bleeding gums, gingivitis, minute petechiae under the skin, nail plates, haemorrhages in the thigh muscles, diarrhoea, and lassitude. Most of the prisoners in our camp had already spent several months in other prisons, where, in some cases, the early symptoms of nutritiona deficiencies had shown themselves. The medicines were dispensed by an experienced nurse or feldsher. For scurvy the only available vitamin was from rosehips, and pneumonia was treated with injections of camphor oil.

I realised that I had to learn to get used to the fact, and never forget it, that I was a prisoner and had to carry out my duties in such a way as not to become involved in friction or controversy and so expose myself to punitive action from the camp authorities. This, however, was unfortunately not always possible.

When I came to take up my responsibilities for the hospital barracks I arranged separate wards for cases of febrile infections, scurvy, and other vitamin deficiencies such as pellagra and nutritional disorders, cardiac conditions, chest disorders, and renal disorders. I had to make my rounds every morning and afternoon assisted by the matron. The work in the wards was fairly relaxing, and I watched the progress of the patients with great satisfaction. When after two or three weeks' stay in the hospital they showed definite improvement and daily recordings were satisfactory they were discharged with a recommendation to be assigned to light work for the next seven to 14 days. From time to time my patients were inspected by $\mathrm{Dr}$ Termoserebian, a Russian lady doctor of Armenian origin, to see whether they were genuinely ill and whether further stay in hospital was justified. From my second month's stay in the camp she did not trouble to hide her animosity towards me. It was, of course, impossible to retain patients with minor ailments or those making a good recovery for long periods as the beds were needed for more severe cases.

Most of the high ranking security officers and nonmedical senior clerks and their families were under my care. On many occasions they offered me tins of caviare out of gratitude for my treatment. I refused to take these, saying that I had never eaten caviare in Poland and that it was very expensive and I did not want to acquire a taste for it. They also offered me cigarettes, which I did not accept either, being a non-smoker. As a prisoner I was paid high wages in camp terms; 50 roubles a month. With this I could buy five or six jars of jam in the camp shop, but there was no need for me to do so as the food supplied was sufficient for my needs. I was also appointed a sanitary inspector of the camp kitchen and bakery, and one of my duties was to taste different dishes and diets. The various diets were prepared and distributed to prisoners according to their jobs, their output of work, and general health. Those whe suffered from severe pellagra were kept in the hospital, where the food was richer in energy and also adjusted to their vitamin requirements, but this higher energy food was not always available.

\section{Pellagra}

One evening in January 1941 three Russian prisoners were admitted to the hospital. They came from a harsh disciplinary camp for prisoners who refused to work, where they were kept on a low energy 


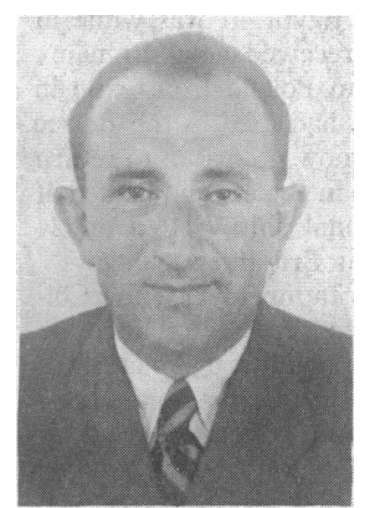

The author in 1947 diet. According to the medical report, they had been found in the snow in a semicomatose condition, and were suffering from pellagra. I was on duty in the hospital, and $\mathrm{Mr}$ Chernishev, concerned for my welfare, arrived to find out whether I could cope. He gave me some guidance about the treatment of pellagra, having wide knowledge and experience of nutritional deficiencies. In his approach to prisoners his behaviour was a mixture of wisdom and benevolence. As I was keen to do everything possible to keep these patients alive he suggested that I try an adrenaline injection into the left ventricle but to do it slowly, warning me at the same time to carry out the treatment in the presence of the duty nurse and not to be disappointed if by the morning all three patients were dead. From his experience and observations of advanced cases of pellagra recovery seldom occurred. By the morning two patients were dead, but the third survived, although he was confused and showed signs of dementia. His condition gradually improved, and eventually he was transferred to a central hospital.

In the previous few weeks I had seen a number of fresh cases of scurvy and pellagra and patients with oedematous legs secondary to malnutrition caused by low protein intake.

The patients with advanced pellagra had mental fatigue, apprehension, depression, inability to concentrate, loss of memory, diarrhoea with prolonged bleeding, and in the more advanced stages disorientation, confusion, and dementia. Clinically, there were characteristic skin lesions on the parts of the body exposed to sunlight, which were separated from the healthy skin by a distinct border. The lesions varied in colour, and in the initial phase they were red, thereafter changing to a reddish brown. When the patient deteriorated the lesions became brown. Some of the patients developed fissures in the pigmented skin. The Russian doctors in the camp summed up this picture by the mnemonic " $5 \mathrm{D}$ "-dermatitis, diarrhoea, dementia, dysfunction of the endocrine glands, and depression. Patients with pellagra were given large doses of nicotinic acid orally and intravenously.

\section{Animosities}

During one morning surgery I had to see a young Russian prisoner, Yakovlenko, who was then 17 . He complained of general fatigue and headache. Just before starting my examination I noticed his slightly swollen face and oedema of both his legs. His blood pressure was raised and his urine showed proteinuria. I handed him a letter for admission to my ward, making a tentative diagnosis of preuraemia. About 15 minutes later Yosef, the feldsher from the other consulting room, rushed into my surgery and asked me whether I knew that Yakovlenko had been discharged as fit the day before from the wards of the Russian lady doctor, Termoserebian. He warned me to be prepared for the most unpleasant repercussions as a result of my diagnosis. At 9 am I was called from hospital to Dr Avchennikova's office, where she vigorously upbraided me.

"Geller," she began, "are you out of your mind? Must you always be reminded that you are a prisoner? Once again by your actions you have shown disloyalty to a respected and experienced free lady doctor."

I tried to justify myself. "I was completely unaware that the prisoner had been discharged as fit only yesterday. He was certainly in poor health when I saw him this morning. It is my responsibility to make an objective diagnosis of every patient I see. Perhaps I was mistaken in admitting the boy to hospital; it is always possible to make human errors."

She stared at me stonily, saying nothing. The seconds ticked by like the passing of hours. I was convinced that she had some unpleasant punishment in mind. At last it came to me that anger in the face of callous injustice does nothing but raise the adrenaline level in one's system. A more subtle response was called for, and what befits the slave better than the mask of,humility? Still she said nothing, and so, having said all I needed to, I left her office. Two hours later the prisoner developed convulsions, and with my diagnosis of uraemia he was admitted to an outside central hospital.

About a week later Dr Termoserebian's animosity towards me burst into the open. She called at my wards and started checking my patients, remarking that one third of them were in good health and should be discharged. When she finished she stopped me in the corridor and ordered me to do a postmortem examination on one of the prisoners who had died in her wards. She said, smiling, "You will have to do it in your room, as we have nowhere else available. Don't worry, the room will be washed clean and painted, and you will be able to sleep in there again next day. After all, you are a prisoner and you have to get used to it. For the night after the postmorten we shall accommodate you in the office room." I could hardly manage to sleep in my room for the next 10 nights.

\section{Relationships}

Sexual problems were dealt with fairly strictly. Relations between prisoners and also between prisoners and people having a free status were forbidden. If sexual relations were proved after investigation both partners were answerable for the "offence." The punishment consisted of moving the people separately to an isolation ward for several days and feeding them bread and water.

Throughout my captivity it was my practice to keep a diary recording events in the camps and the names of people I encountered. As this was expressly forbidden by the prison authorities my notes, which were written as small as possible on long thin strips of paper, had to be hidden for me by some of the very professional criminals who were my fellow captives and whose respect and even devotion I was fortunate enough to have inspired. I always found these men to be more trustworthy than the so called "intelligentsia."

\section{Freedom and a second life in medicine}

I learnt that the camp was to be wound down and all the prisoners transferred by train to the northern part of Russia. Our transport left the camp at the end of April, and we arrived in Kaninosa on 8 or 9 May 1941.

I left the second camp at the end of May on foot with a company of about 350 Russian prisoners and a few Lithuanians, escorted by several guards. The roads were covered with snow and it was bitterly cold. It was a tedious day, and I had only one piece of bread to eat. By the evening our echelon reached a forest after a march of about $40 \mathrm{~km}$ and the guards ordered us to rest. In the morning we were moved from the forest to a hilly open area and had to wait for a doctor from a nearby hospital, whose function it was to find out whether any of us were unfit for a further long walk. Vladimir, the hospital feldsher, concluded that I was not fit for further walking and said that the chief medical officer would decide on my fate. On arrival at the hospital I was introduced to the chief medical officer, and as my records were handed to him he tore up the order in my presence and said cheerfully that he would be pleased to have me in his hospital. Thus I found myself in Komi Republic. Hospital.

On 30 August 1941 there was an unexpected knock on my door. When I opened it the messenger told me with great excitement that all the Poles were to be set 
free. In this camp, situated so far in the north behind the Pechora river, it seemed like a dream, totally divorced from reality. I was one of the first in the hospital to whom this historic message was delivered. I was called to the KGB office in the hospital, where the officer in charge proclaimed my freedom in a ceremonial way. He suggested that I remain in Russia as a free doctor; I would be offered a good position owing to my experience and fluent Russian. I could settle down to start a new life. The officer warned me that north Russia was the safest place at that time as Russia had just joined the war against the Nazis. I expressed my thanks and explained that my parents were in Yoshkar Ola and my duty was to find them, and that I would look for a job in a hospital to be near enough to help. The officer shook hands with me and wished me every success.

I was soon on my way to Tockoye to join the new Polish army, which was assembling there. I subsequently served with this body in Uzbekistan, Iran,
Iraq, Palestine, Kenya, and Egypt. It was while in Egypt in April 1946 that I received news from my parents, who had returned to Poland from exile in Russia, that my wife, Zosia, had died in the Belzec concentration camp. Having now no reason to return to Poland, I resolved to settle in Britain and landed at Southampton from the hospital ship El Nil on 24 November 1947. I have lived in Britain ever since.

Recently I received an invitation to visit the Collegium Novum in Cracow to receive an honorary degree. In view of the improving political climate there I may well go despite the strong emotions that such a visit to my native country would generate even now, nearly 50 years after I last set foot there.

Dr Geller's book, Through Darkness to Dawn, based partly on his secret diaries, was published this year by the Veritas Foundation. It is also available from the agent, Mr G Fraser, 35 Copse Avenue, W Wickham, Kent; price $£ 4.00$ (including postage).

\title{
Medicine on the move
}

\author{
Peter Godfrey-Faussett
}

Did I know anybody who wanted to spend six weeks as the medical officer for the British Police Karakoram Expedition in 1989? With a contract that finished in June and a research post starting in September it was a pleasant daydream so here I was, sitting in the snow on a glacier nearly $4900 \mathrm{~m}$ up, six days walk from the nearest village, surrounded by 150 Balti porters asking for tablets. I perched awkwardly on my lightweight rucksack, warm in my duvet jacket, and sheltered from the sun by wide brimmed hat and goggles. The porters squatted comfortably on their heels, each wrapped in a coarse woollen blanket, his $25 \mathrm{~kg}$ load sitting beside him on the snow. We could have come from different planets.

Our team of $17 \mathrm{members} \mathrm{had} \mathrm{flown} \mathrm{out} \mathrm{to} \mathrm{Islamabad,}$ but the weather was too bad too fly on to Skardu, the main town in Baltistan. The 28 hour bus journey into Pakistan's northern areas was an unforgettable experience. The Karakoram highway clings optimistically to the sides of the gorge carved by the river Indus. With each terrifying hairpin bend we uttered silent prayers,

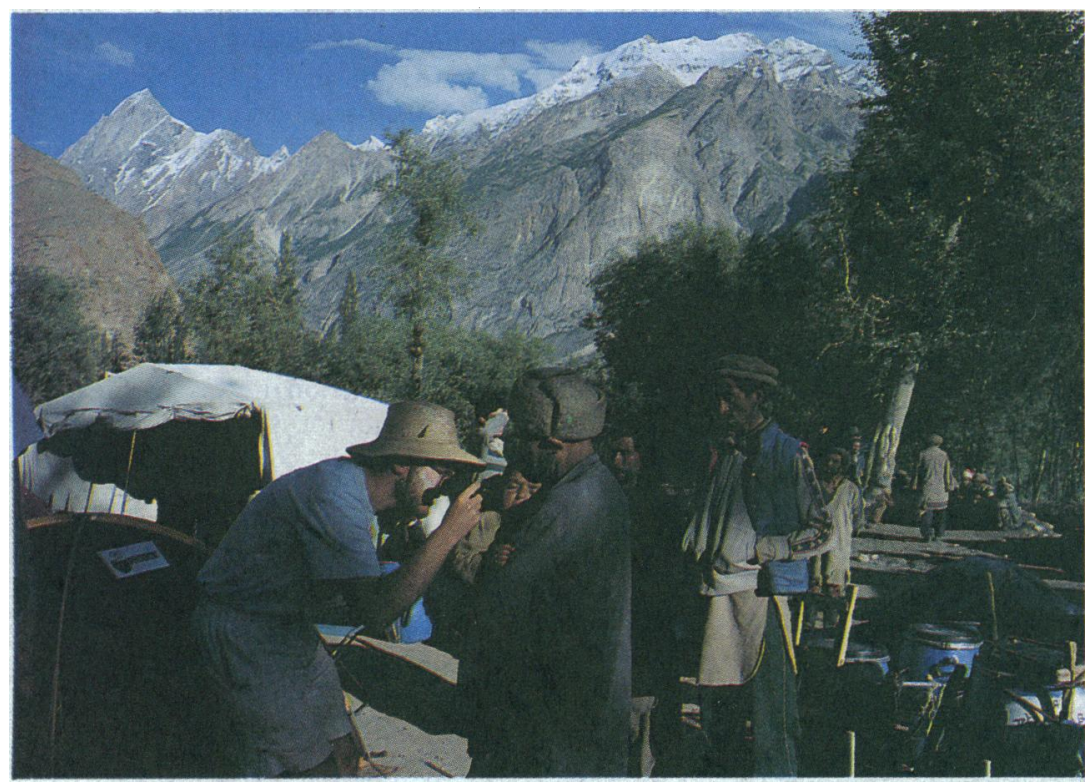

Examining a child's ear at Askole (3700 m) and those who had chosen to travel on top of the bus (where leg room was more generous) clung to our luggage stacked around them. Sleep was almost impossible, although at times I thought that the driver had managed.

From Skardu the road deteriorated and we continued our journey in jeeps, leaving the Indus and following the Braldu river until the track petered out. It was a considerable relief to start walking; at least you control your own destiny. We passed through the treacherous Braldu gorge, crossing precipitous scree slopes covered with dust, where each step sent rocks crashing down into the torrent, before turning north on to the massive Biafo glacier. Each day's walk ended with an unforgiving scramble over the broken ice and rubble of the lateral moraine to reach the campsite. No sooner were the tents up and the tea brewed than the porters started gathering for evening surgery.

The pressure to give out tablets was huge. Even the sirdar's English was limited to discussions of campsites and load sizes; symptoms were therefore described with anguished faces and eloquent gestures. Who would not ache after a day toiling up the glacier in the fierce sun with an ungainly barrel strapped to his back?

As the days went by, patterns emerged. A headache earned two paracetamol tablets, but the man who convinced me that his abdominal pain came on after he ate was given an antacid. The size of the antacid pills was at least five times that of the paracetamol so the next day headaches were forgotten and rows of soft bellies exposed. An old man with a toothless grin assured me that his knee was near to collapse. In a sentimental moment I offered him a tubular support bandage. Next day they were all the rage, and I noted that their principal use was to keep the snow out of the tops of the porters' rubber ankle boots. Even the old man queued up to explain that yesterday's bandage had been lost. This time I was firm, and sure enough he was wearing it the next day.

A porter in the Himalayas or Karakoram has a very hard life, and no pill of mine will change that. Furthermore, to walk day in day out over hostile mountain terrain the porters have to be fit, strong, and healthy. They have wildly inaccurate ideas about the power of Western medicine. I believe that some assume that I hold a panacea that will let them into the 